\title{
Smart Growth and Vulnerability to Crisis in the EU Regions - Evaluation with Logistic Regression
}

\author{
Małgorzata MARKOWSKA \\ Wrocław University of Economics, Wrocław, Poland \\ malgorzata.markowska@ue.wroc.pl
}

\begin{abstract}
The paper discusses the relations among variables characterizing smart growth of the EU NUTS 2 level regions and sensitivity to economic crisis. First, the procedure identifying the status of being in crises is presented for individual regions in individual years. Initial variables reflect the changes in macroeconomic data. Division by median was used for the kind of standardization. Four groups of regions are identified by means of cluster analysis: sensitive, adaptive, robust and outliers. Then the first selection of significant explaining variables is performed by means of parametric (Student $t$ ) and nonparametric (Mann-Whitney $U$ ) tests for the two expected values. The final list of important and independent factors is obtained through the stepwise multivariate logistic regression. The final goal is to find some spheres of smart development having the highest influence on robustness against economic crisis improvement. ROC curves with AUC measures prove models identifying robust regions, and separately vulnerable to crisis regions, to be fairly good.
\end{abstract}

Keywords: Logit Models, Smart Growth, Vulnerability, Classification, NUTS 2 Regions.

\section{Introduction}

The identification of determinants which either stimulate, or do not influence the sensitivity to crisis, or constitute the basis of countries' and regions' robustness against economic turbulences represent the significant challenge in economic research. The European Union regions, just like the global economy, were coping with the crisis at the end of the first decade of the current century with various effects. Therefore investigating methods and tools, allowing the successful identification of economic areas to be improved in order to reduce economic deadlocks, turns out an important problem in the discussed context [6,9]. Logistic regression models, suggested in the subject literature for the first time in 1944 [3], representing the classical binary classification models (the explanatory variable can take two values only) and allowing the impact evaluation of $X_{1}, X_{2}, \ldots, X_{K}$ explanatory variables on $Y$ dichotomous variable, seem appropriate for this purpose.

The purpose of the study is to present the proposal of logit models application in the identification of economic strategic areas, in terms of regional smart growth, in the context of their vulnerability to crisis phenomena, along with the results 
verification of variables' relations characterizing smart growth of the European Union NUTS 2 level regions along with sensitivity to economic crisis.

\section{Logit models - theoretical basis}

In the discussed models the dependent variable is a dichotomous one (takes two values -0 and 1). It is useful in the situation when an event presence or absence of the phenomenon to be predicted has to be determined. The dichotomous variable values can be converted into the probability of a particular event occurrence. The application of logit transformation (as the link function) allows the linearization of logistic regression model and the application of a model from the generalized linear models class. The obtained regression equation allows calculating the probability of a particular event occurrence for the predictor values used in the model. The values of model parameters are estimated by maximum likelihood method. The model formula used in this study is presented below (1):

$$
P(Y=1)=\frac{\exp \left(\beta_{0}+\beta_{1} X_{1}+\beta_{2} X_{2}+\cdots+\beta_{m} X_{m}\right)}{1+\exp \left(\beta_{0}+\beta_{1} X_{1}+\beta_{2} X_{2}+\cdots+\beta_{m} X_{m}\right)}
$$

The so-called odds ratio is useful in the interpretation of results (relative risk) comparing the odds of an event occurrence for a given value against the baseline value or the unit increase of the explanatory variable value.

Various applications of logit models in regional science are reviewed in Markowska [14]. The range of logit models' application refers not only to macro, but also to mezzo and micro scale, whereas this review of research areas shows that the spectrum of their applications in economic research is extremely wide.

\section{Smart growth - measurement}

In the EU strategic documents smart growth is approached as the improvement of results in terms of [3]:

- education by encouraging towards education, studying and improving qualifications,

- research and innovation by developing new products and services influencing economic growth, employment and facilitating solutions to social problems,

- digital society, i.e. the implementation of information and communication technologies.

D. Strahl's team [10, 11] - in project Classification of the European regional space in the light of smart growth concept - dynamic presentation, grant NCN 2011/01/B/HS4/04743 - suggested the following variables, grouped in three pillars (smart specialization, creative regions, innovations), to measure smart growth based on the review of database resources and availability assessment: 
Pillar I - smart specialization, smart specialization indicators (whether a given variable is a stimulant (S) or a destimulant (D) was indicated in brackets):

- $\mathrm{SS}_{1}$ - workforce employed in knowledge-intensive services as the share of workforce employed in services $(\mathrm{S})$,

- $\mathrm{SS}_{2}$ - average growth rate of workforce in knowledge-intensive services as the share of workforce employed in services (S),

- $\mathrm{SS}_{3}$ - workforce in mid and high-tech industry sector (as \% of workforce employed in industry) (S),

- $\mathrm{SS}_{4}$ - average working rate of workforce in mid and high-tech industry sector (as $\%$ of workforce employed in industry) (S).

Pillar II - creative regions, creativity indicators:

- $\mathrm{CR}_{1}$ - share of tertiary education workforce in the total workforce number in a region $(\mathrm{S})$,

- $\mathrm{CR}_{2}$ - share of population aged 25-64 participating in life-long learning in a region $(\mathrm{S})$,

- $\mathrm{CR}_{3}$ - human capital for science and technology as \% of working population (S),

- $\mathrm{CR}_{4}$ - people aged 15-64 born in a different country as \% of population aged 15-64 $(\mathrm{S})$,

- $\mathrm{CR}_{5}$ - unemployment rate as \% of active population (D),

- $\mathrm{CR}_{6}$ - basic creative class (\% of population aged 15-64) (S),

- $\mathrm{CR}_{7}$ - share of residents in their working age who moved from different EU regions in the recent year $(\mathrm{S})$,

- $\mathrm{CR}_{8}$ - tertiary education graduates aged 30-34 (\% of population aged 30-34) (S),

- $\mathrm{CR}_{9}-$ access to broadband internet (\% of households (S).

- Pillar III - innovation, indicators of innovation potential, capacity and effects:

- $\mathrm{IN}_{1}$ - patents registered in the European Patent Office (EPO) per 1 million of workforce $(\mathrm{S})$,

- $\mathrm{IN}_{2}$ - productivity in industry and services (PPS per worker) index EU27=100 (S),

- $\mathrm{IN}_{3}$ - employment rate (\% of population aged 20-64) (S),

- $\mathrm{IN}_{4}$ - investments in private sector per 1 inhabitant by purchasing power parity (S),

- $\mathrm{IN}_{5}-\mathrm{R} \& \mathrm{D}$ expenditure in business (GDP \%) (S),

- $\mathrm{IN}_{6}-\mathrm{R} \& \mathrm{D}$ expenditure (GDP \%) (S).

\section{The evaluation of relations between smart growth and vulnerability to economic crisis of the European Union regions using logit models}

\subsection{The identification of regions sensitive to crisis}

The above-mentioned sets of variables were used in the evaluation of relations between sensitivity to crisis and smart growth in each of the identified areas 
(economy, job market and households) and the results were presented in e.g.: $[8,12$, $13,15,16,17]$. In the present study we use the below presented variables (data from the years 2005-2011) or, in fact, their change rate was used for the overall dynamic classification of regions [12], in order to identify the sensitivity to crises:

- RC_GDP - GDP in millions PPS in a region (S) - change rate,

- RC_IN - investments in millions euro in a region $(\mathrm{S})$ - change rate,

- RC_ER - employment rate (\% of working population) (S) - change rate,

- RC_UR - unemployment rate (destimulant) (D) - change rate,

- RC_WA - wages in millions euro in a region (S) - change rate,

- RC_IH - disposable income per capita in a household in PPS (S) - change rate.

The algorithm of procedure after specifying the set of variables covered [12]:

- determining medians of each characteristic based on all years under observation;

- normalization - dividing spatial-temporal data by the median - the advantages of the applied standardization: leaves the change rate mark: negative means deterioration, positive shows improvement; reduces all variables to equal validity and although formally it is not a weight system, it can be assumed that in an initial stage the original rates are weighted by $1 / \mathrm{Me}$ weights. Moreover, it leaves the outliers, quite different from the rest (which do not result in artificial distribution compression, as it happens in case of dividing by standard deviation);

- dynamic taxonomy [5], including the identification of the number of groups based on the data cube (objects -264 regions analysed jointly (excluding Croatian (4) and overseas: French (4) and Spanish (2), in accordance with the system in force [4]) - for all 6 years $(6 * 264)$, which resulted in 1584 rows and 6 columns number of variables - using Ward method and the final classification using $k$ means method.

The dendrogram obtained by Ward method and the selected classification results are presented below (Fig. 1 and Tab. 1). The dendrogram clearly indicates the occurrence of four groups of operational taxonomic units.

In 2008 the following regions have been classified as sensitive and robust (explanations of acronyms are provided at the end of the article):

- sensitive (56): IE01, IE02, EL43, ES22, ES23, ES24, ES30, ES41, ES42, ES51, ES52, ES53, ES61, ES62, ES70, FR41, ITH4, ITF3, ITG2, HU21, PT18, SE32, UKC1, UKC2, UKD1, UKD3, UKD4, UKD6, UKD7, UKE1, UKE2, UKE3, UKE4, UKF1, UKF2, UKF3, UKG1, UKG2, UKG3, UKH1, UKH2, UKH3, UKI2, UKJ1, UKJ2, UKJ4, UKK1, UKK2, UKK3, UKL1, UKL2, UKM2, UKM3, UKM5, UKM6, UKN0;

- robust (38): BG31, BG32, BG33, BG34, BG41, BG42, CZ01, CZ06, CZ08, PL11, PL12, PL21, PL22, PL31, PL32, PL33, PL34, PL41, PL42, PL43, PL51, PL52, PL61, PL62, PL63, RO11, RO12, RO21, RO22, RO31, RO32, RO41, RO42, SK01, SK02, SK03, SK04, FI20. 
Table 1. Dynamic cluster analysis results based on 2005-2011 period. Average change rate in groups. [12]

\begin{tabular}{lrrrrrrrr}
\hline $\begin{array}{l}\text { Group } \\
\text { name }\end{array}$ & $\begin{array}{c}\text { Taxonomic } \\
\text { units }\end{array}$ & RC_GDP & RC_WA & RC_IN & RC_IH & RC_ER & RC_UR \\
& Number & $\%$ & & & & & & \\
\hline Sensitive & 408 & 25.8 & -0.71 & -0.89 & -1.30 & -0.40 & -1.35 & -2.19 \\
Adaptive & 961 & 60.7 & 0.80 & 0.92 & 0.50 & 0.79 & 0.56 & 0.30 \\
Robust & 202 & 12.8 & 1.79 & 3.42 & 2.73 & 1.48 & 1.48 & 1.16 \\
Outliers & 13 & 0.8 & -1.35 & -22.35 & -1.67 & -4.21 & -4.21 & -2.98 \\
\hline
\end{tabular}

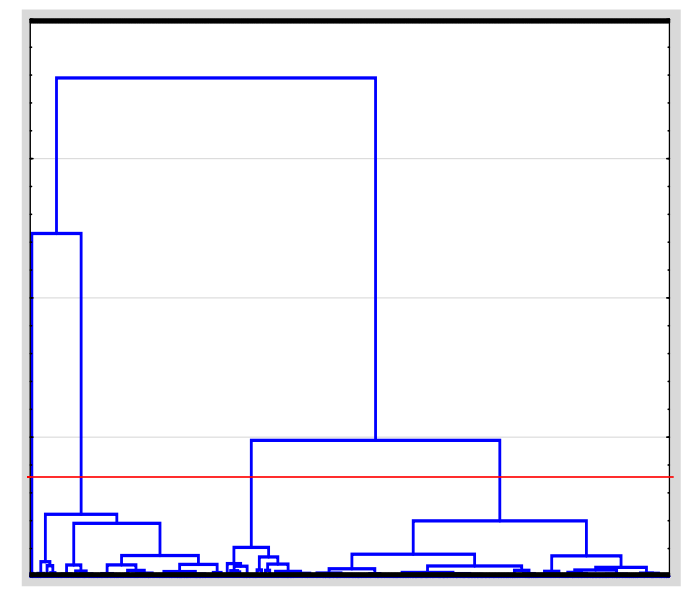

Fig. 1. Dendrogram of dynamic cluster analysis of temporal-regions. [12]

The data for smart growth variables were collected: from $2007\left(\mathrm{SS}_{1}, \mathrm{SS}_{3}, \mathrm{CR}_{1}-\mathrm{CR}_{3}\right.$ and $\mathrm{CR}_{5}, \mathrm{CR}_{6}, \mathrm{CR}_{8}, \mathrm{CR}_{9}, \mathrm{IN}_{1}-\mathrm{IN}_{3}, \mathrm{IN}_{5}$ and $\left.\mathrm{IN}_{6}\right)$; from $2008\left(\mathrm{CR}_{4}\right)$; from the years 2007-2008 $\left(\mathrm{CR}_{7}\right)$; from the years $2002-2006\left(\mathrm{IN}_{4}\right)$; from the years $2000-2007\left(\mathrm{SS}_{2}\right.$, $\left.\mathrm{SS}_{4}\right)$.

\subsection{The evaluation of relations between smart growth and robustness to economic crisis of the European Union regions}

Initially a univariate model was constructed for each variable identifying smart growth pillars, in which the explanatory variable, marked as 1 , identified the regions robust to crisis. The odds ratios obtained, based on univariate models, along with the significance evaluation are presented in Table 2.

It was not possible to estimate sensible models for two variables ( $\mathrm{IN}_{1}$ and $\mathrm{IN}_{4}$ ) because of measure units. Individual difference of these variables resulted in microscopic risk changes. The values were converted so that $\mathrm{IN}_{1}$ were presented in hundreds and $\mathrm{IN}_{4}$ in thousands of theirs original units. 
Table 2. Odds ratios from logistic models and tests results comparing two groups - robust against crisis (code 1$)$ vs. the rest (code 0$)$.

\begin{tabular}{|c|c|c|c|c|c|c|c|c|}
\hline $\begin{array}{r}\text { Variable } \\
\end{array}$ & $\begin{array}{c}\text { Odds ratio } \\
\text { (relative risk) }\end{array}$ & p-value & 0 & $\begin{array}{ll} & 1 \\
x^{2} & \end{array}$ & $\begin{array}{l}\text { t test p-value } \\
\text { (two-tailed) }\end{array}$ & $\begin{array}{c}\text { M-W test } \\
\text { p-value }\end{array}$ & $\mathbf{0}$ & Me \\
\hline$\overline{\mathrm{SS}_{1}}$ & 0.897 & 0.0000 & 49.08 & 42.54 & 0.0000 & 0.0000 & 49.85 & 42.04 \\
\hline $\mathrm{SS}_{2}$ & 0.627 & 0.0056 & 100.84 & 100.54 & 0.0154 & 0.0165 & 100.74 & 100.37 \\
\hline $\mathrm{SS}_{3}$ & 0.955 & 0.0196 & 23.30 & 19.32 & 0.0019 & 0.0092 & 23.52 & 18.00 \\
\hline $\mathrm{SS}_{4}$ & 1.081 & 0.1819 & 99.78 & 100.49 & 0.2529 & 0.1214 & 99.95 & 100.66 \\
\hline $\mathrm{CR}_{1}$ & 0.905 & 0.0001 & 28.01 & 21.36 & 0.0000 & 0.0000 & 28.45 & 20.92 \\
\hline $\mathrm{CR}_{2}$ & 0.701 & 0.0000 & 10.79 & 4.02 & 0.0000 & 0.0000 & 8.30 & 3.73 \\
\hline $\mathrm{CR}_{3}$ & 0.885 & 0.0000 & 36.89 & 29.04 & 0.0000 & 0.0000 & 36.65 & 27.00 \\
\hline $\mathrm{CR}_{4}$ & 0.083 & 0.0000 & 6.59 & 0.34 & 0.0000 & 0.0000 & 5.66 & 0.16 \\
\hline $\mathrm{CR}_{5}$ & 1.178 & 0.0027 & 6.67 & 8.39 & 0.0019 & 0.0004 & 6.10 & 8.50 \\
\hline $\mathrm{CR}_{6}$ & 2.125 & 0.0000 & 66.51 & 70.59 & 0.0000 & 0.0000 & 66.13 & 70.67 \\
\hline $\mathrm{CR}_{7}$ & 0.078 & 0.0000 & 1.33 & 0.35 & 0.0000 & 0.0000 & 1.02 & 0.29 \\
\hline $\mathrm{CR}_{8}$ & 0.911 & 0.0000 & 30.34 & 21.40 & 0.0000 & 0.0000 & 30.35 & 21.85 \\
\hline $\mathrm{CR}_{9}$ & 0.932 & 0.0000 & 46.45 & 26.73 & 0.0000 & 0.0000 & 47.73 & 29.99 \\
\hline $\mathrm{IN}_{1}$ & 0.00005 & 0.0001 & 1.93 & 0.09 & 0.0000 & 0.0000 & 1.27 & 0.04 \\
\hline $\mathrm{IN}_{2}$ & 0.907 & 0.0000 & 101.02 & 58.80 & 0.0000 & 0.0000 & 102.62 & 54.99 \\
\hline $\mathrm{IN}_{3}$ & 0.857 & 0.0000 & 67.24 & 59.61 & 0.0000 & 0.0000 & 67.75 & 58.65 \\
\hline $\mathrm{IN}_{4}$ & 0.161 & 0.0000 & 3.91 & 1.68 & 0.0000 & 0.0000 & 3.74 & 1.20 \\
\hline $\mathrm{IN}_{5}$ & 0.008 & 0.0000 & 1.02 & 0.19 & 0.0000 & 0.0000 & 0.71 & 0.11 \\
\hline $\mathrm{IN}_{6}$ & 0.045 & 0.0000 & 1.59 & 0.47 & 0.0000 & 0.0000 & 1.17 & 0.34 \\
\hline
\end{tabular}

Next, the average values were compared in the groups of robust regions and other regions by means of a parametric test for two average values (with separate variance estimation) and Mann-Whitney U test.

All three methods gave a substantively identical results. Only one variable $\left(\mathrm{SS}_{4}\right)$ did not show the ability to differentiate the robust regions from the rest and was omitted in the multivariate model building procedure. The logistic regression model was estimated using STATISTICA 12 program in Generalized linear and nonlinear models module. A multivariate logistic regression approach was applied with the criterion of adding and deleting variables $\mathrm{p}=0.05$. The results are presented in Table 3.

Table 3. Multidimensional logistic regression model estimation results for regions robust against crisis.

\begin{tabular}{cccc}
\hline Variable & Odds ratio & $\mathbf{9 5 \%}$ C.I. & p-value \\
\hline $\mathrm{SS}_{1}$ & 1.65 & $1.13-2.41$ & 0.0101 \\
$\mathrm{SS}_{3}$ & 0.63 & $0.44-0.90$ & 0.0103 \\
$\mathrm{CR}_{4}$ & 0.001 & $0.000-0.233$ & 0.0122 \\
$\mathrm{CR}_{5}$ & 0.47 & $0.25-0.88$ & 0.0189 \\
$\mathrm{CR}_{6}$ & 3.92 & $1.33-11.55$ & 0.0132 \\
$\mathrm{IN}_{5}$ & 0.0004 & $0.0000-0.1236$ & 0.0072 \\
\hline
\end{tabular}


ROC curve (Fig. 2) illustrates the very good model ability to identify the regions robust against crisis. All characteristics of this identification tool show very good values: AUC (Area Under Curve) $=0.997$, Sensitivity $=0.947$, Specificity $=0.987$, PPV $($ Positive Predictive Value $)=0.923$, NPV $($ Negative Predictive Value $)=0.991$.

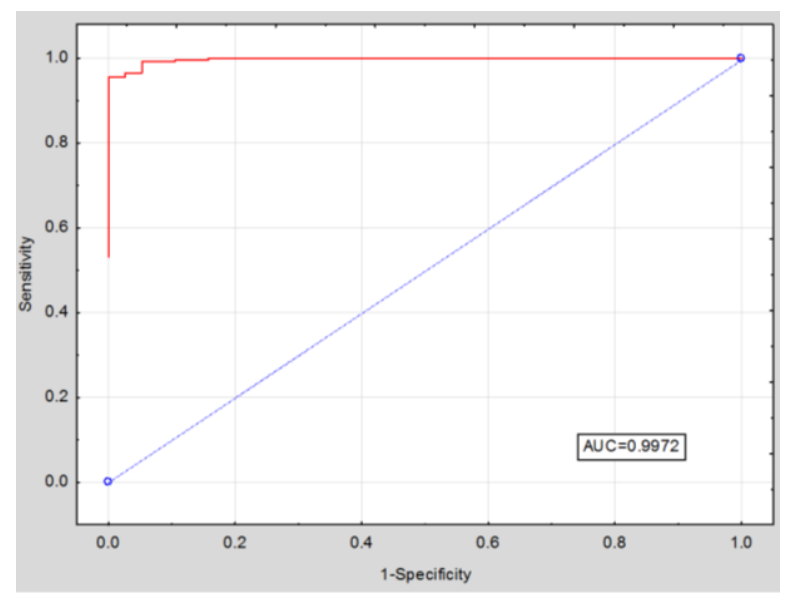

Fig. 2. ROC curve for model identifying regions robust against crisis.

The economic interpretation of the model should be approached with great caution having in mind that the illustrated relationships do not represent a cause-effect relation. The increasing values of two variables referring to job market strengthen regional chances to be included in the regions robust to crisis. It is the percentage of employment in knowledge-based services as the share of employment in services $\left(\mathrm{SS}_{1}\right)$ and the percentage of population aged 15-64 $\left(\mathrm{CR}_{5}\right)$. Unemployment rate increase reduces the chances of robustness against crisis $\left(\mathrm{CR}_{5}\right)$, likewise the share of immigrants $\left(\mathrm{CR}_{4}\right)$. The activities in industry sector, both in the period of its modern branches development, as well as investments in research and development reduce the changes of regional robustness against crisis.

\subsection{The evaluation of relationships between smart growth and sensitivity to economic crisis of the European Union regions}

This section presents estimation results of the logistic regression model in terms of a region included in the group of regions sensitive to crisis vs. other regions. First a univariate analysis was conducted using a univariate logistic regression models, the test for two average values and Mann-Whitney U test were performed (Table 4). These variables were eliminated from the preliminary list of explanatory variables for which the absence of difference significance was confirmed by all tests (i.e. the following variables $\mathrm{SS}_{2}, \mathrm{SS}_{3}, \mathrm{CR}_{3}, \mathrm{IN}_{2}, \mathrm{IN}_{5}$ and $\mathrm{IN}_{6}$ ). 
Table 4. Odds ratios from logistic models and results of tests comparing two groups vulnerable to crisis (code 1) vs. the rest (code 0).

\begin{tabular}{lccrrrrrr}
\hline Variable & $\begin{array}{c}\text { Odds ratio } \\
\text { (relative } \\
\text { risk) }\end{array}$ & $\begin{array}{c}\text { p- } \\
\text { value }\end{array}$ & \multicolumn{1}{c}{$\mathbf{0}$} & $\mathbf{1}$ & $\begin{array}{c}\text { t test } \\
\text { p-value } \\
\text { (two- } \\
\text { tailed) }\end{array}$ & $\begin{array}{c}\text { M-W } \\
\text { test } \\
\text { p-value }\end{array}$ & Me & \\
\hline $\mathrm{SS}_{1}$ & 1.039 & 0.0386 & 47.58 & 50.22 & 0.0293 & 0.0056 & 47.37 & 53.21 \\
$\mathrm{SS}_{2}$ & 1.163 & 0.2923 & 100.71 & 100.89 & 0.2243 & 0.4603 & 100.73 & 100.69 \\
$\mathrm{SS}_{3}$ & 0.982 & 0.2696 & 23.07 & 21.47 & 0.2088 & 0.3982 & 23.19 & 21.93 \\
$\mathrm{SS}_{4}$ & 0.793 & 0.0001 & 100.28 & 98.40 & 0.0000 & 0.0000 & 100.40 & 98.52 \\
$\mathrm{CR}_{1}$ & 1.076 & 0.0001 & 25.84 & 31.55 & 0.0000 & 0.0000 & 24.95 & 31.73 \\
$\mathrm{CR}_{2}$ & 1.150 & 0.0000 & 8.42 & 15.01 & 0.0000 & 0.0000 & 7.07 & 17.70 \\
$\mathrm{CR}_{3}$ & 1.013 & 0.4754 & 35.57 & 36.48 & 0.3648 & 0.4372 & 36.00 & 35.85 \\
$\mathrm{CR}_{4}$ & 1.086 & 0.0031 & 5.17 & 7.61 & 0.0044 & 0.0029 & 4.61 & 5.64 \\
$\mathrm{CR}_{5}$ & 0.835 & 0.0034 & 7.21 & 5.82 & 0.0001 & 0.0046 & 6.80 & 5.45 \\
$\mathrm{CR}_{6}$ & 0.876 & 0.0488 & 67.26 & 66.49 & 0.0169 & 0.1136 & 66.52 & 66.24 \\
$\mathrm{CR}_{7}$ & 1.317 & 0.0344 & 1.11 & 1.46 & 0.0285 & 0.0037 & 0.70 & 1.15 \\
$\mathrm{CR}_{8}$ & 1.067 & 0.0002 & 27.46 & 34.97 & 0.0000 & 0.0000 & 25.95 & 34.50 \\
$\mathrm{CR}_{9}$ & 1.020 & 0.0230 & 42.28 & 48.57 & 0.0060 & 0.0208 & 42.00 & 51.50 \\
$\mathrm{IN}_{1}$ & 0.685 & 0.0030 & 1.86 & 0.93 & 0.0000 & 0.1855 & 1.19 & 0.72 \\
$\mathrm{IN}_{2}$ & 0.999 & 0.8508 & 95.11 & 94.31 & 0.7839 & 0.3394 & 99.90 & 94.24 \\
$\mathrm{IN}_{3}$ & 1.102 & 0.0002 & 65.27 & 69.39 & 0.0000 & 0.0000 & 65.85 & 70.25 \\
$\mathrm{IN}_{4}$ & 1.161 & 0.0751 & 3.49 & 3.96 & 0.0238 & 0.0214 & 3.40 & 3.83 \\
$\mathrm{IN}_{5}$ & 1.061 & 0.6915 & 0.89 & 0.95 & 0.7031 & 0.4048 & 0.57 & 0.59 \\
$\mathrm{IN}_{6}$ & 1.029 & 0.2273 & 1.42 & 1.46 & 0.8147 & 0.4748 & 1.10 & 1.11 \\
\hline & & & & & & & &
\end{tabular}

The multivariate model constructed based on the stepwise multivariate logistic regression application is presented in Table 5 and ROC curve on Graph 3.

The obtained model confirms the importance of job market to economic crisis sensitivity. Higher share of population aged 15-64 in the total population number reduces the risk of a region being classified in the group sensitive to crisis, whereas the risk goes up along with higher share of people born in a foreign country. Both higher share of tertiary education workforce and the participation in life-long learning increase the vulnerability to crisis. The reason may be sought in an inadequate structure of the qualified personnel. In turn, the definitely "protective" (against crisis) role is played by economy innovation measured in terms of patent number.

Table 5. Multidimensional logistic regression model estimation results for regions vulnerable to crisis.

\begin{tabular}{cccc}
\hline Variable & Odds ratio & 95\% C.I. & p-value \\
\hline $\mathrm{CR}_{2}$ & 1.24 & $1.14-1.34$ & 0.0000 \\
$\mathrm{CR}_{4}$ & 1.10 & $1.02-1.19$ & 0.0120 \\
$\mathrm{CR}_{6}$ & 0.75 & $0.62-0.91$ & 0.0039 \\
$\mathrm{CR}_{8}$ & 1.05 & $1.00-1.10$ & 0.0462 \\
$\mathrm{IN}_{1}$ & 0.16 & $0.08-0.31$ & 0.0000 \\
\hline
\end{tabular}


Attention should be paid to the regions incorrectly qualified by the last model. Among the twenty regions incorrectly not qualified as sensitive (actually sensitive, which was not shown by the equation) the following are included: both Irish (Border, Midlands and Western and Southern and Eastern), eight British (Cheshire, Est Yorkshire and Northern Lincolnshire, Derbyshire and Nottinghamshire, East Anglia, Bedfordshire, Hertfordshire, Berkshire, Bucks and Oxfordshire, Surrey, East and West Sussex, Northern Ireland), three Spanish (Comunidad Foral de Navarra, Cataluna, Andalucia) and three Italian (Friuli-Venezia Giulia, Campania, Sardegna), Greek (Kriti), French (Lorraine), Hungarian (Közép-Dunántúl) and Portuguese (Alentejo). Whereas the group of regions incorrectly classified as sensitive included 11 following regions: Région de Bruxelles-Capitale (BE), Hovedstaden (DE), Cyprus (CY), Flevoland (NL), Zahodna Slovenija (SI), Åland (FI), Övre Norrland (SI) as well as two British (Inner London, Devon) and two Spanish (Extremadura, Galicia).

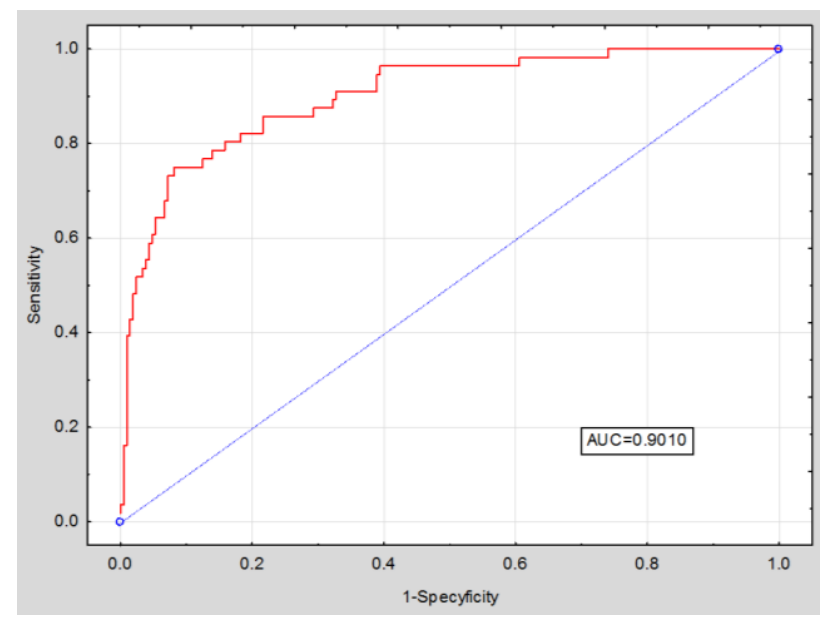

Fig. 3. ROC curve for the model identifying regions vulnerable to crisis.

The quality characteristics of the classification of regions by the model, i.e. sensitivity 0.643; specificity: 0.947; positive predictive value: 0.766 and negative predictive value: 0.908 indicate that the model can be used in determining that a region is not sensitive to crisis, since if the model indicates that the probability of it being true amounts to 0.908 , which shows that it is suitable for excluding sensitivity.

\section{Conclusions}

Logit models, apart from their applications, discussed in the presented review, can also turn out useful in the identification of factors enhancing or reducing crisis phenomena in regions. The suggested research concept, i.e.:

- identifying groups of regions either robust or sensitive to crisis using dynamic taxonomy, 
- evaluating - for each group - the significance of variables illustrating smart growth pillars based on univariate logit models (using e.g.: the test for two average values and Mann-Whitney U test),

- constructing for both multivariate model groups obtained as a result of stepwise multivariate logistic regression application (adding and deleting variables),

- evaluating model quality in terms of ROC curve and parameters (sensitivity, specificity, PPV and NPV),

allowed, due to a very good, in both cases, model ability of identifying robust and sensitive regions (ROC curve) to identify the relations among variables selected for smart growth assessment and: 1/ robustness and 2/ sensitivity of regions to economic crisis.

The identification of job market elements such as the share of employment in knowledge-based services and the overall share of productive age workforce resources in population number (basic creative class) represent important factors as the determinants constituting the "protective buffer" against regional vulnerability to crisis.

Moreover, it should be emphasized that the crisis of the first decade of the $21^{\text {st }}$ century has had a much larger impact on "wealthy" countries and regions, which resulted e.g. from an overproduction of banking products (caused by the lack of moderation in meeting the needs) [1]. Less developed countries and regions in terms of e.g. high technologies experienced, at that time, the effects of allocating structural funds, including pre-accession ones (Bulgarian and Romanian regions) and the prolonged effects of financing from the years 2004-2006 and 2007-2013 (e.g. Polish regions [7]).

Acknowledgements. The study carried out within the framework of the project no. 2015/17/B/HS4/01021, entitled Smart growth vs. sectoral transformations in the European regional space - measurement methods, financed by the National Science Centre.

\section{References}

1. Bartosiewicz, S.: Głos w dyskusji na temat przyczyn kryzysów gospodarczych. In: Pawełek, B. (ed.) Modelowanie i prognozowanie zjawisk społeczno-gospodarczych, Cracow University of Economics Press, Cracow, (2014).

2. Berkson, J.: Application of the Logistic Function to Bio-assay. Journal of the American Statistical Association 39(227), 357-365 (1944).

3. European Commission: Europe 2020. A strategy for smart, sustainable and inclusive growth. Brussels: European Commission. Communication from the Commission. COM/2010/2020 final.

4. European Commission: (2011). Regions in the European Union. Nomenclature of territorial unit for statistics NUTS 2010/EU-27. Luxembourg: European Commission. Series: Methodologies and Working Papers. 
5. Markowska, M.: Dynamiczna taksonomia innowacyjności regionów. Wrocław University of Economics Press, Monographs and Studies 221, Wrocław (2012).

6. Markowska, M.: Ocena zależności między rozwojem inteligentnym a odpornością na kryzys ekonomiczny w wymiarze regionalnym - przegląd badań. Research Papers of Wrocław University of Economics 333, 22-32 (2014), DOI: 10.15611/pn.2014.333.02.

7. Markowska, M.: A measure for regional resilience to economic crisis. STATISTICS IN TRANSITION 16(2), 293-308 (2015).

8. Markowska, M.: Ocena wrażliwości na kryzys gospodarstw domowych w unijnych regionach - analiza przestrzenno-czasowa. Research Papers of Wrocław University of Economics 393, 53-66 (2015), DOI:10.15611/pn.2015.393.05.

9. Markowska, M.: The vulnerability of regions to economic crisis - measurement problems. In: Hlavacek, P., Olsova, P. (eds.) Regional Economy and Policy. Territory and Cities. Jan Evangelista Purkyne University, pp. 104-112. Usti nad Labem (2015).

10. Markowska, M., Strahl, D.: European regional space classification regarding smart growth level. Comparative Economic Research. Central and Eastern Europe 15(4), 233-247 (2012), DOI: https://doi.org/10.2478/v10103-012-0038-2.

11. Markowska, M., Strahl, D.: Klasyfikacja europejskiej przestrzeni regionalnej ze względu na filary inteligentnego rozwoju z wykorzystaniem referencyjnego systemu granicznego. Research Papers of Wrocław University of Economics 327, Taxonomy 22, 121-130 (2014).

12. Markowska, M., Strahl, D.: Wykorzystanie klasyfikacji dynamicznej do identyfikacji wrażliwości na kryzys ekonomiczny unijnych regionów szczebla NUTS 2. Research Papers of Wrocław University of Economics 385, Taxonomy 25, 166-177 (2015), DOI:10.15611/pn.2015.385.18.

13. Markowska, M., Strahl, D.: Filary inteligentnego rozwoju a wrażliwość unijnych regionów szczebla NUTS 2 na kryzys ekonomiczny - analiza wielowymiarowa. Research Papers of Wrocław University of Economics 426, Taxonomy 26, 118-129 (2016), DOI: 10.15611/pn.2016.426.12.

14. Markowska, M.: Brief review of logit models applications in regional studies. Research Papers of Wrocław University of Economic 476, 11-17 (2017), DOI:10.15611/pn.2017.476.01.

15. Markowska, M., Sokołowski, A., Strahl, D., Sobolewski, M.: Klasyfikacja dynamiczna regionów Unii Europejskiej szczebla NUTS 2 z uwagi na wrażliwość na kryzys ekonomiczny (obszar: zmiany w gospodarce). Research Papers of Wrocław University of Economics 393, 32-44 (2015), DOI:10.15611/pn.2015.393.03.

16. Markowska, M., Sokołowski, A., Strahl, D., Sobolewski, M.: Klasyfikacja dynamiczna regionów Unii Europejskiej szczebla NUTS 2 pod względem wrażliwości na kryzys ekonomiczny w obszarze rynek pracy. Humanities and Social Sciences 22, 37-50 (2015), DOI:10.7862/rz.2015.hss.18.

17. Strahl, D., Sokołowski, A.: Propozycja podejścia metodologicznego do oceny zależności między inteligentnym rozwojem a wrażliwością na kryzys ekonomiczny w wymiarze regionalnym. Research Papers of Wrocław University of Economics 331, 190-200 (2014), DOI: $10.15611 / \mathrm{pn} .2014 .331 .18$.

\section{Annex (list of regions and acronyms):}

BG31 Severozapaden, BG32 Severen tsentralen, BG33 Severoiztochen, BG34 Yugoiztochen, BG41 Yugozapaden, BG42 Yuzhen tsentralen, CZ01 Praha, CZ06 Jihovýchod, CZ08 Moravskoslezsko, IE01 Border, Midland and Western, IE02 Southern and Eastern, EL43 Kriti, ES22 Comunidad Foral de Navarra, ES23 La 
Rioja, ES24 Aragón, ES30 Comunidad de Madrid, ES41 Castilla y León, ES42 Castilla-la Mancha, ES51 Cataluña, ES52 Comunidad Valenciana, ES53 Illes Balears, ES61 Andalucía, ES62 Región de Murcia, ES70 Canarias, FR41 Lorraine, ITH4 Friuli-Venezia Giulia, ITF3 Campania, ITG2 Sardegna, HU21 Közép-Dunántúl, PL11 Łódzkie, PL12 Mazowieckie, PL21 Małopolskie, PL22 Śląskie, PL31 Lubelskie, PL32 Podkarpackie, PL33 Świętokrzyskie, PL34 Podlaskie, PL41 Wielkopolskie, PL42 Zachodniopomorskie, PL43 Lubuskie, PL51 Dolnośląskie, PL52 Opolskie, PL61 Kujawsko-pomorskie, PL62 Warmińsko-mazurskie, PL63 Pomorskie, PT18 Alentejo, RO11 Nord-Vest, RO12 Centru, RO21 Nord-Est, RO22 Sud-Est, RO31 Sud - Muntenia, RO32 Bucuresti-Ilfov, RO41 Sud-Vest Oltenia, RO42 Vest, SK01 Bratislavský kraj, SK02 Západné Slovensko, SK03 Stredné Slovensko, SK04 Východné Slovensko, FI20 Åland, SE32 Mellersta NorrlandUKC1 Tees Valley and Durham, UKC2 Northumberland and Tyne and Wear, UKD1 Cumbria, UKD3 Greater Manchester, UKD4 Lancashire, UKD6 Cheshire, UKD7 Merseyside, UKE1 East Yorkshire and Northern Lincolnshire, UKE2 North Yorkshire, UKE3 South Yorkshire, UKE4 West Yorkshire, UKF1 Derbyshire and Nottinghamshire, UKF2 Leicestershire, Rutland and Northamptonshire, UKF3 Lincolnshire, UKG1 Herefordshire, Worcestershire and Warwickshire, UKG2 Shropshire and Staffordshire, UKG3 West Midlands, UKH1 East Anglia, UKH2 Bedfordshire and Hertfordshire, UKH3 Essex, UKI2 Outer London, UKJ1 Berkshire, Buckinghamshire and Oxfordshire, UKJ2 Surrey, East and West Sussex, UKJ4 Kent, UKL1 West Wales and The Valleys, UKL2 East Wales, UKM2 Eastern Scotland, UKM3 South Western Scotland, UKM5 North Eastern Scotland, UKM6 Highlands and Islands, UKNO Northern Ireland. 